\title{
PENGARUH KEBIJAKAN DIVIDEN, LEVERAGE, DAN UKURAN PERUSAHAAN TERHADAP VOLATILITAS HARGA SAHAM
}

\author{
Ni Luh Putu Sintya Marini ${ }^{1}$ \\ Sayu Ketut Sutrisna Dewi \\ ${ }^{1,2}$ Fakultas Ekonomi dan Bisnis Universitas Udayana (Unud), Bali, Indonesia \\ email: sintya.marin@gmail.com
}

\begin{abstract}
ABSTRAK
Volatilitas harga saham mencerminkan fluktuasi pergerakan harga saham dan tingkat risiko yang dihadapi oleh investor. Penelitian ini menguji pengaruh kebijakan dividen, leverage, dan ukuran perusahaan terhadap volatilitas harga saham. Variabel penelitian diukur dengan dividen payout ratio, debt to equity ratio, dan logaritma natural total aset. Penelitian ini dilakukan pada sampel 19 perusahaan sektor properti, real estate, dan konstruksi yang terdaftar di Bursa Efek Indonesia (BEI) dan membagikan dividen berturut-turut selama periode 2013-2017. Teknik analisis yang digunakan adalah regresi linear berganda. Hasil analisis menunjukkan bahwa secara simultan kebijakan dividen, leverage, dan ukuran perusahaan berpengaruh terhadap volatilitas harga saham. Secara parsial, kebijakan dividen dan ukuran perusahaan berpengaruh negatif terhadap volatilitas harga saham sedangkan leverage berpengaruh positif terhadap volatilitas harga saham.

Kata Kunci: dividen; leverage; ukuran perusahaan; volatilitas
\end{abstract}

\begin{abstract}
Stock price volatility reflects the fluctuations on stock price movements and the level of risk faced by investors. This research examines the impact of dividend policy, leverage, and firm size on stock price volatility. The research variables were measured by dividend payout ratio, debt to equity ratio, and natural logarithm of total assets. This research was conducted on 19 samples of property, real estate, and construction sector companies listed in Indonesia Stock Exchange (IDX) that distributed consecutive dividends during 20132017. Multiple linear regression used as the analysis technique. The analysis result shows that simultaneously dividend policy, leverage, and firm size influence stock price volatility. Partially dividend policy and firm size has negative impact on stock price volatility while leverage has positive impact on stock price volatility.

Keywords : dividend; leverage; firm size; volatility
\end{abstract}




\section{PENDAHULUAN}

Investasi didefinisikan sebagai komitmen atas sejumlah dana atau sumber daya lainnya yang dilakukan pada saat ini, dengan tujuan mendapat keuntungan di masa yang akan datang (Tandelilin, 2010: 2). Ketika memutuskan untuk berinvestasi dalam bentuk saham, investor mengharapkan imbalan berupa pendapatan baik dalam bentuk dividend yield maupun capital gain. Dividend yield adalah arus kas yang dibayarkan secara periodik kepada pemegang saham (dalam bentuk dividen), sedangkan capital gain adalah keuntungan penjualan saham akibat selisih dari harga jual saham dengan harga belinya (Hartono, 2015:267). Investor biasanya menggunakan harga saham sebagai dasar pertimbangan karena nilai perusahaan dicerminkan oleh harga saham (Theresia dan Arilyn, 2015). Harga saham akan mengalami perubahan pada keadaan tertentu, tergantung pada kondisi pasar baik dari kinerja keuangan perusahaan yang menerbitkan saham maupun keinginan investor untuk membeli saham tersebut. Naik turunnya harga saham dapat dilihat melalui volatilitas. Volatilitas menurut Hartono (2015:713) menunjukkan risiko sistematik dari aset atau portofolio. Volatilitas harga saham adalah pengukuran statistik untuk fluktuasi pergerakan harga saham, dimana harga saham bergerak secara drastis di kedua arah (Ramadan, 2013). Volatilitas harga saham yang tinggi dapat menyebabkan kesulitan bagi investor untuk memprediksi harga saham di masa mendatang serta ketidakpastian return yang akan diperoleh investor juga semakin tinggi karena perusahaan dengan harga saham volatil keuntungan masa depannya secara relatif lebih sulit diramalkan (Rohmawati, 2017).

Faktor-faktor yang mempengaruhi volatilitas harga saham dikelompokkan ke dalam tiga kategori oleh Madura (2014) yaitu faktor ekonomi (faktor yang akan mempengaruhi cash flow perusahaan seperti pertumbuhan ekonomi, kebijakan pemerintah, tingkat suku bunga, nilai tukar mata uang asing dan inflasi), faktor pasar (sentimen investor dapat menyebabkan harga saham meningkat bahkan saat perekonomian sedang lemah karena investor mengharapkan perekonomian akan membaik di masa mendatang serta January effect juga berpengaruh terhadap harga saham karena banyak manajer portofolio memilih berinvestasi pada saham perusahaan kecil yang berisiko di awal tahun kemudian beralih kepada saham yang lebih stabil saat mendekati akhir tahun untuk memperoleh keuntungan), dan faktor internal perusahaan (pengumumanpengumuman seperti kebijakan dividen, keputusan perusahaan untuk melakukan akuisisi dan divestasi, dan laporan keuangan perusahaan untuk melihat faktor fundamental perusahaan). Fahmi (2012:89), mengemukakan bahwa faktor-faktor yang dapat mempengaruhi volatilitas harga saham yaitu kondisi mikro dan makro ekonomi, kebijakan dalam memutuskan berekspansi, membuka kantor cabang, pergantian direksi, direksi perusahaan terlibat tindak pidana, kinerja perusahaan yang terus mengalami penurunan, risiko sistematis, dan efek psikologis dari pasar.

Penelitian ini dilakukan pada sektor properti, real estate, dan konstruksi dimana sektor tersebut merupakan salah satu indikator perkembangan perekonomian suatu negara. Perusahaan-perusahaan yang terdaftar pada sektor properti, real estate, dan konstruksi bergerak di bidang pembangunan dan pengembangan rumah, gedung, jalan, dan fasilitas umum lainnya. Adapun sektor 
ini dibagi menjadi dua sub sektor yaitu sub sektor properti dan real estate serta sub sektor konstruksi dan bangunan. Perusahaan sektor properti, real estate, dan konstruksi di Bursa Efek Indonesia memiliki harga saham yang cukup berfluktuasi. Pembangunan tempat tinggal, gedung kantor, pusat perbelanjaan, tempat rekreasi, sekolah, dan lain-lain berlangsung secara terus-menerus dan berkembang mengikuti jaman yang semakin canggih, namun tetap saja harga saham perusahaan-perusahaan sektor properti, real estate, dan konstruksi berfluktuasi karena adanya faktor-faktor seperti kemampuan masyarakat untuk membeli properti dan respon dan reaksi yang berbeda dari setiap informasi yang terdapat di pasar.

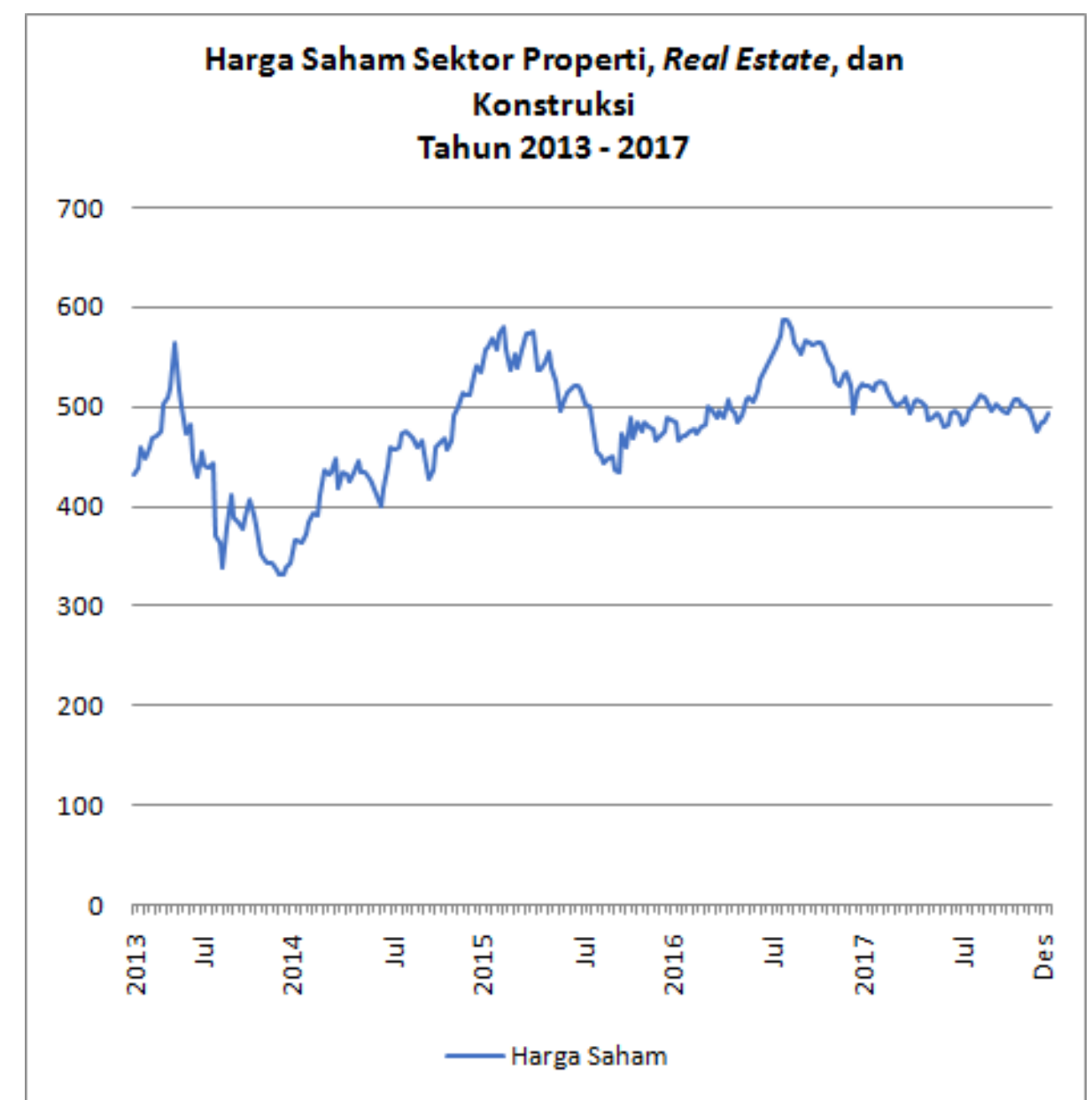

Gambar 1. Grafik Perkembangan Harga Saham Sektor Properti, Real Estate, dan Konstruksi Tahun 2013-2017

Sumber: www.idx.co.id, data diolah 2018

Harga saham sektor properti, real estate, dan konstruksi terlihat mengalami fluktuasi sepanjang periode 2013-2017. Harga saham sektor properti, real estate, dan konstruksi sepanjang tahun 2013 cenderung mengalami penurunan dengan indeks sektor mencapai 22,26 persen. Pada tahun 2014, harga saham mengalami kecenderungan meningkat dan mencapai indeks sektor 55,76 persen namun pada tahun 2015 menurun drastis mencapai angka minus 6,47 persen. Pada tahun 2016, 
indeks sektor properti, real estate, dan konstruksi berhasil naik menjadi 18,7 persen dan kembali mengalami penurunan pada tahun 2017 hingga mencapai angka minus 4,31 persen. (www.investasi.kontan.co.id). Dari persentase peningkatan dan penurunan indeks sektor properti, real estate, dan konstruksi dapat diasumsikan bahwa harga saham perusahaan-perusahaan sektor ini cukup volatil.

Penelitian ini menggunakan variabel kebijakan dividen, leverage, dan ukuran perusahaan. Kebijakan dividen merupakan keputusan perusahaan mengenai pembagian laba kepada pemegang saham sebagai dividen atau penahanan laba berupa laba ditahan untuk berinvestasi di masa datang (Sartono, 2014:281). Kebijakan dividen merupakan salah satu petunjuk perusahaan yang dapat mengurangi perbedaan informasi mengenai kondisi dan prospek perusahaan antara manajemen perusahaan dan investor (Profilet dan Bacon, 2013). Informasi tentang kebijakan dividen akan memberikan sinyal mengenai prospek kinerja jangka panjang kepada investor sehingga investor berani menanamkan modalnya pada perusahaan. Kebijakan dividen merupakan salah satu faktor penting yang harus diperhatikan oleh manajemen dalam mengelola perusahaan karena memiliki pengaruh yang signifikan terhadap pihak perusahaan maupun pemegang saham. Bagi perusahaan, pembagian dividen akan mengurangi kas perusahaan sehingga dana yang tersedia untuk membiayai kegiatan operasi maupun reinvestasi akan berkurang. Bagi pemegang saham, dividen merupakan satu bentuk pengembalian atas investasi mereka. Kebijakan dividen diproksikan dengan dividend payout ratio. Dividend payout ratio merupakan perbandingan antara dividen per lembar saham dengan laba per lembar saham.

Penelitian terkait pengaruh kebijakan dividen yang diproksikan dengan dividend payout ratio terhadap volatilitas harga saham dilakukan oleh Hussainey, Mgbame, dan Chijoke-Mgbame (2011) pada perusahaan go-public di Britania Raya dengan periode 10 tahun menggunakan metode regresi berganda memperoleh hasil kebijakan dividen berpengaruh negatif terhadap volatilitas harga saham. Hasil yang sama juga ditemukan oleh Nazir et al. (2012) pada 75 sampel perusahaan sektor keuangan di Pakistan dengan metode regresi fixed effect, Hashemijoo et al. (2012) pada 84 sampel perusahaan produk barang konsumsi di Malaysia dengan metode regresi berganda, Profilet dan Bacon (2013) pada 599 perusahaan di pasar modal Amerika Serikat dengan metode regresi Ordinary Least Squares (OLS), Al-Shawawreh (2014) pada 53 sampel perusahaan yang terdaftar di sektor industri, pelayanan, bank, dan asuransi di pasar modal Yordania dengan metode regresi berganda, serta Hooi et al. (2015) pada 319 perusahaan di pasar modal Malaysia. Hasil yang berbeda ditemukan oleh Priana dan Muliartha (2017) yang meneliti 13 perusahaan pada indeks LQ 45 di BEI periode 2013-2015, Sharif et al. (2017) yang meneliti 45 perusahaan nonkeuangan pada indeks KSE-100 di Pakistan dengan periode 12 tahun, serta Rohmawati (2017) yang meneliti 9 perusahaan pada indeks LQ 45 di BEI periode 2011-2015 memperoleh hasil dividend payout ratio berpengaruh positif terhadap volatilitas harga saham. Penelitian yang dilakukan oleh Gunarathne et al. (2015) pada 12 perusahaan manufaktur di Sri Lanka dengan metode data panel, serta Ananda dan Mahdy (2015) pada 11 perusahaan konsumsi di Bursa Efek Indonesia 
(BEI) menemukan bahwa tidak adanya pengaruh antara dividend payout ratio dengan volatilitas harga saham.

Signaling theory berpendapat bahwa suatu kenaikan dividen yang diatas kenaikan normal biasanya merupakan suatu sinyal kepada para investor bahwa manajemen perusahaan meramalkan suatu penghasilan yang baik dimasa yang akan datang. Sebaliknya, suatu penurunan dividen yang dibawah penurunan normal diyakini investor sebagai suatu sinyal bahwa perusahaan menghadapi masa sulit dimasa mendatang (Brigham, 2011:215). Perusahaan yang melakukan pembagian dividen secara rutin akan lebih dipilih oleh investor karena memiliki risiko yang lebih rendah. Perusahaan yang memiliki prospek kepastian lebih besar, akan mempunyai harga saham yang tinggi dan tidak berubah-ubah, sehingga dikatakan kebijakan dividen berpengaruh negatif terhadap volatilitas harga saham.

Penelitian yang dilakukan oleh Nazir et al. (2012) pada 75 sampel perusahaan sektor keuangan di Pakistan dengan metode regresi fixed effect, Profilet dan Bacon (2013) pada 599 perusahaan di pasar modal Amerika Serikat dengan metode regresi Ordinary Least Squares (OLS), Khurniaji dan Raharja (2013) pada 70 perusahaan non-keuangan periode 2009-2011 di Bursa Efek Indonesia dengan metode regresi linear berganda, Al-Shawawreh (2014) pada 53 sampel perusahaan yang terdaftar di sektor industri, pelayanan, bank, dan asuransi di pasar modal Yordania dengan metode regresi berganda, dan Hooi et al. (2015) pada 319 perusahaan pasar modal di Malaysia menunjukkan bahwa kebijakan dividen berpengaruh negatif terhadap volatilitas harga saham. Penelitian yang menyatakan bahwa kebijakan dividen berpengaruh negatif terhadap volatilitas harga saham menunjukkan bahwa semakin besar dividen yang dibagikan perusahaan, maka tingkat volatilitas harga saham semakin rendah.

$\mathrm{H}_{1}$ : Kebijakan dividen berpengaruh negatif terhadap volatilitas harga saham.

Leverage adalah kemampuan perusahaan dalam memenuhi kewajiban jangka pendek maupun jangka panjang atau dengan kata lain mengukur seberapa besar perusahaan dibiayai dengan utang (Wiagustini, 2014:85). Leverage diproksikan dengan Debt to Equity Ratio (DER). Menurut Husnan dan Pudjiastuti (2012:72), debt to equity ratio adalah rasio yang menunjukkan perbandingan antara utang dengan modal sendiri. Perusahaan dengan DER yang tinggi mencerminkan risiko keuangan yang dimiliki relatif tinggi karena perusahaan cenderung tergantung pada utang yang menyebabkan laba perusahaan berkurang karena kewajiban membayar utang beserta bunganya, dimana hal ini berdampak pada resiko investasi yang lebih tinggi (Harahap, 2009:303). Semakin tinggi DER, volatilitas harga saham akan meningkat karena perusahaan diasumsikan memiliki risiko yang tinggi terhadap likuiditas perusahaannya (Jannah dan Haridhi, 2016).

Penelitian terkait pengaruh leverage yang diproksikan dengan debt to equity ratio (DER) terhadap volatilitas harga saham dilakukan oleh Nazir et al. (2014) pada 17 perusahaan sektor keuangan di Pakistan menunjukkan hasil bahwa leverage berpengaruh positif signifikan terhadap volatilitas harga saham. Hasil yang sama juga ditemukan oleh penelitian Jannah dan Haridhi (2016) pada 195 perusahaan non-keuangan di BEI periode 2010-2014. Hasil yang berbeda ditemukan oleh Nazir et al. (2010) di Pakistan, Profilet dan Bacon (2013) di Amerika Serikat, serta Priana dan Muliartha (2017) di Indonesia menunjukkan 
bahwa leverage berpengaruh negatif terhadap volatilitas harga saham. Hasil penelitian Dewi dan Suaryana (2016) pada 18 perusahaan indeks LQ 45 periode 2010-2014 serta Ardiansyah dan Isbanah (2017) pada 14 perusahaan sektor aneka industri peiode 2013-2015 menunjukkan bahwa leverage tidak berpengaruh terhadap volatilitas harga saham.

Kasmir (2014:112) menyatakan bahwa leverage menunjukkan sejauh mana penggunaan utang dalam membiayai aktivitas perusahaan. Semakin tinggi DER, maka risiko perusahaan relatif tinggi karena kecenderungan perusahaan bergantung pada utang dalam melaksanakan aktivitasnya sehingga perusahaan pun akan mengalami pengurangan laba untuk memenuhi kewajiban membayar bunga utang (Sulia dan Rice, 2013). Trade off theory merupakan teori yang menyatakan bahwa perusahaan yang melakukan pendanaan dengan utang yang besar semakin berisiko untuk mengalami kesulitan keuangan akibat pembayaran bunga tetap yang terlalu besar setiap tahunnya dengan ketidakpastian laba bersih yang diperoleh (Mardiyati et al., 2012).

Penelitian yang dilakukan oleh Nazir et al. (2014) pada 17 perusahaan sektor keuangan periode 2007-2012 dengan metode data panel di Pakistan dan Jannah dan Haridhi (2016) pada 195 perusahaan non-keuangan periode 2010-2014 dengan metode regresi berganda di Indonesia menunjukkan bahwa leverage berpengaruh positif terhadap volatilitas harga saham. Leverage berpengaruh positif berarti semakin tinggi leverage suatu perusahaan, volatilitas harga sahamnya pun semakin tinggi, begitu pula sebaliknya.

$\mathrm{H}_{2}$ : Leverage berpengaruh positif terhadap volatilitas harga saham.

Faktor lain yang dapat mempengaruhi volatilitas harga saham adalah ukuran perusahaan (firm size). Ukuran perusahaan adalah suatu skala dimana besar kecilnya suatu perusahaan dapat diklasifikasikan menurut total aset, penjualan bersih, dan kapitalisasi pasar perusahaan (Murniati, 2015). Semakin besar total aset atau penjualan bersih perusahaan, maka akan semakin besar ukuran perusahaan dan begitu pula sebaliknya, semakin rendah total aset atau penjualan bersih perusahaan, maka ukuran perusahaan semakin kecil. Investor yang bersikap hati-hati cenderung memperhitungkan besar kecilnya perusahaan saat menanamkan dananya dalam bentuk saham. Ukuran perusahaan pada dasarnya dapat dikategorikan menjadi 3 (tiga) yaitu perusahaan besar (large firm), perusahaan menengah (medium firm), dan perusahaan kecil (small firm). Ukuran perusahaan yang diproksikan melalui $\ln$ total aset dapat memberikan informasi bagi para pelaku pasar modal bahwa perusahaan dapat mengelola aktivitas bisnisnya dengan baik dan ini akan mempengaruhi sikap investor (Ananda dan Mahdy, 2015). Perusahaan dengan ukuran yang besar cenderung memiliki diversifikasi aktivitas perusahaan yang besar sehingga informasi mengenai perusahaan juga semakin mudah diakses oleh publik. Informasi yang mudah di akses akan mengurangi keraguan investor dalam menanamkan modalnya dan mengurangi tingkat volatilitas harga saham (Selpiana dan Badjra, 2018).

Penelitian terkait pengaruh ukuran perusahaan dengan proksi ln total aset terhadap volatilitas harga saham dilakukan oleh Zakaria et al. (2012) pada 77 perusahaan sektor konstruksi dan material di Malaysia periode 2005-2010 dengan metode regresi least squares memperoleh hasil bahwa ukuran perusahaan 
berpengaruh positif terhadap volatilitas harga saham. Hasil yang sama juga diperoleh oleh Al-Shawawreh (2014) di Yordania et al. (2015) pada 12 perusahaan manufaktur di Sri Lanka dengan metode data panel, dan Khan, Waleed et al. (2017) pada 42 perusahaan sektor tekstil, gula, dan bahan kimia di pasar modal Karachi. Hasil yang berbeda ditemukan oleh Anastasia dan Firnanti (2014), Theresia dan Arylin (2015), dan Selpiana dan Badjra (2018) yang melakukan penelitian di Bursa Efek Indonesia dan memperoleh hasil penelitian yang menunjukkan bahwa ukuran perusahaan berpengaruh negatif terhadap volatilitas harga saham, sedangkan Ardiansyah dan Isbanah (2017) dalam penelitiannya memperoleh hasil bahwa ukuran perusahaan tidak berpengaruh terhadap volatilitas harga saham.

Menurut Hashemijoo et al. (2012) saham perusahaan kecil lebih likuid sehingga harga saham lebih volatil. Hal ini karena semakin besar ukuran perusahaan, maka aktivitas yang dilakukan juga semakin beragam sehingga lebih banyak informasi yang dapat dibagikan kepada publik dan dapat mengurangi tingkat volatilitas harga saham. Penelitian yang dilakukan Profilet dan Bacon (2013) di Amerika Serikat, Anastasia dan Firnanti (2014) pada 76 perusahaan non-keuangan periode 2009-2012 di Indonesia, Qudah dan Yusuf (2015) pada perusahaan industrial selama periode 2001-2011 dengan metode regresi multiple least squares di Yordania, serta Selpiana dan Badjra (2018) pada 24 perusahaan dari indeks LQ 45 di BEI periode 2012-2016 menunjukkan ukuran perusahaan berpengaruh negatif terhadap volatilitas harga saham. Hasil ini menunjukkan bahwa semakin besar ukuran suatu perusahaan, maka volatilitas harga sama perusahaan akan semakin rendah atau harga sahamnya semakin stabil.

$\mathrm{H}_{3}$ : Ukuran perusahaan berpengaruh negatif terhadap volatilitas harga saham.

Adanya fenomena volatilitas harga saham tersebut membuat peneliti tertarik untuk meneliti volatilitas harga saham pada sektor properti, real estate, dan konstruksi. Berdasarkan penelitian-penelitian terdahulu mengenai pengaruh kebijakan dividen, leverage, dan ukuran perusahaan terhadap volatilitas harga saham masih terdapat perbedaan pada hasil-hasil penelitian (research gap). Oleh karena itu peneliti akan meneliti lebih lanjut pengaruh variabel kebijakan dividen, leverage, dan ukuran perusahaan terhadap volatilitas harga saham pada sektor properti, real estate, dan konstruksi.

Berdasarkan latar belakang masalah, maka rumusan masalah dari penelitian ini adalah: 1) apakah kebijakan dividen berpengaruh terhadap volatilitas harga saham?, 2) apakah leverage berpengaruh terhadap volatilitas harga saham?, 3) apakah ukuran perusahaan berpengaruh terhadap volatilitas harga saham?. Tujuan dari penelitian ini yaitu: 1) untuk menguji dan menjelaskan pengaruh kebijakan dividen terhadap volatilitas harga saham, 2) untuk menguji dan menjelaskan pengaruh leverage terhadap volatilitas harga saham, 3) untuk menguji dan menjelaskan pengaruh ukuran perusahaan terhadap volatilitas harga saham.

Penelitian ini memiliki manfaat teoritis dan manfaat praktis. Manfaat teoritis penelitian ini yaitu dapat berguna untuk menambah bukti empiris di bidang manajamen keuangan yang terkait dengan volatilitas harga saham, kebijakan dividen, leverage, dan ukuran perusahaan. Manfaat praktis penelitian ini yaitu memberikan informasi tambahan bagi perusahaan sebagai pertimbangan dasar 
pengambilan keputusan keuangan untuk meningkatkan pencapaian investasi saham yang optimum bagi perusahaan dan bagi investor sebagai dasar pengambilan keputusan investasi perusahaan di pasar modal dilihat dari pembagian dividennya, rasio leverage, serta ukuran perusahaan.

Berdasarkan latar belakang masalah serta kajian teoritis dan empiris yang telah dipaparkan sebelumnya, maka kerangka konseptual antara variabel dependen yaitu volatilitas harga saham dengan variabel independen yaitu kebijakan dividen, leverage, dan ukuran perusahaan disusun sebagai berikut:

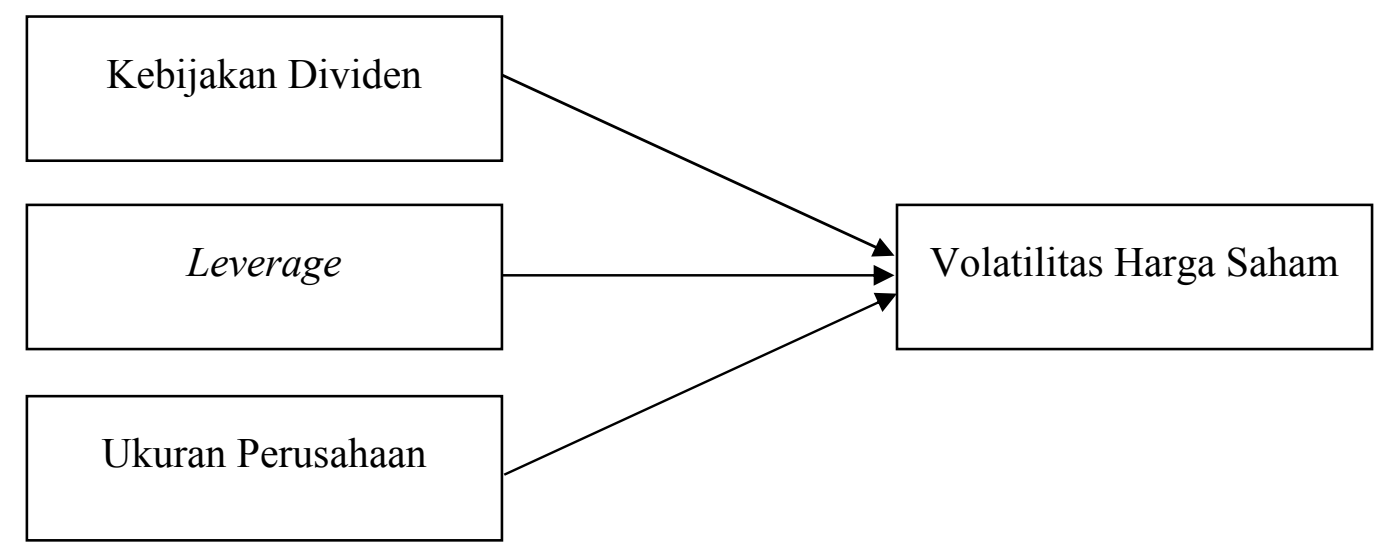

Gambar 2. Kerangka Konseptual

\section{METODE PENELITIAN}

Desain penelitian ini menggunakan pendekatan kuantitatif berbentuk asosiatif untuk meneliti pengaruh kebijakan dividen, leverage, dan ukuran perusahaan terhadap volatilitas harga saham. Lokasi penelitian ini dilaksanakan di Bursa Efek Indonesia pada sektor properti, estate, dan konstruksi periode 20132017. Obyek penelitian ini adalah volatilitas harga saham sebagai variabel dependen (Y) dan kebijakan dividen, leverage, ukuran perusahaan sebagai variabel independen $(\mathrm{X})$.

Volatilitas harga saham dalam penelitian ini merupakan jenis historical volatility yang menggunakan data historis harga tertinggi dan harga terendah saham yang menjadi sampel pada sektor properti, real estate, dan konstruksi di Bursa Efek Indonesia periode 2013-2017. Volatilitas harga saham dinyatakan dalam bentuk persentase. Rumus perhitungan volatilitas harga saham adalah sebagai berikut (Priana dan Muliartha, 2017):

$$
\mathrm{PV}=\sqrt{\frac{1}{\mathrm{n}} \sum \ln \left(\frac{\mathrm{H} i}{\mathrm{~L} i}\right)^{2}}
$$

Keterangan:

PV = Volatilitas Harga Saham

$\mathrm{n} \quad=$ Jumlah sampel data

$\ln \quad=$ logaritma natural

$\mathrm{H} i=$ Harga saham tertinggi pada tahun $i$ 
$\mathrm{L} i \quad=$ Harga saham terendah pada tahun $i$

Kebijakan dividen dalam penelitian ini diproksikan dengan dividend payout ratio (DPR). DPR merupakan perbandingan antara dividen per lembar saham dengan laba per lembar saham. DPR dinyatakan dalam bentuk persentase dengan rumus perhitungan sebagai berikut (Jannah dan Haridhi, 2016):

$$
\text { Dividen payout ratio }=\frac{\text { Dividen per Lembar Saham }}{\text { Laba per Lembar saham }}
$$

Leverage dalam penelitian ini diproksikan dengan Debt to Equity Ratio (DER). DER merupakan perbandingan antara total utang dengan total modal sendiri. DER dinyatakan dalam bentuk persentase dengan rumus perhitungan sebagai berikut (Fahmi, 2016:73):

$$
\text { Debt to Equity Ratio }=\frac{\text { Total Utang }}{\text { Total Modal Sendiri }}
$$

Ukuran perusahaan dapat diklasifikasikan berdasarkan total aset. Ukuran perusahaan diukur dengan logaritma natural (ln) dari total aset perusahaan. Secara matematis, rumus perhitungan ukuran perusahaan adalah sebagai berikut (Lashgari dan Ahmadi, 2014):

Ukuran perusahaan $=$ Logaritma natural dari total aset

Populasi yang digunakan dalam penelitian ini adalah seluruh perusahaan sektor properti, real estate, dan konstruksi di Bursa Efek Indonesia yaitu sebanyak 69 perusahaan dengan rincian 52 perusahaan tergolong sub sektor Properti dan real estate dan 17 perusahaan lainnya tergolong sub sektor konstruksi dan bangunan. Metode pengumpulan sampel yang digunakan dalam penelitian ini adalah metode purposive sampling dengan kriteria sebagai berikut:

Tabel 1.

Kriteria Penentuan Sampel

\begin{tabular}{clc}
\hline No & \multicolumn{1}{c}{ Keterangan } & $\begin{array}{c}\text { Jumlah } \\
\text { Perusahaan }\end{array}$ \\
\hline 1 & $\begin{array}{l}\text { Populasi Perusahaan Sektor Properti, Real Estate, dan Konstruksi } \\
\text { di Bursa Efek Indonesia }\end{array}$ & 69 \\
2 & $\begin{array}{l}\text { Perusahaan terdaftar di Bursa Efek Indonesia setelah tahun 2012 } \\
\text { Jumlah perusahaan yang telah terdaftar di Bursa Efek Indonesia } \\
\text { paling lambat tahun 2012 }\end{array}$ & 49 \\
4 & $\begin{array}{l}\text { Perusahaan yang tidak membagikan dividen berturut-turut dari } \\
\text { tahun buku 2013 - 2017 }\end{array}$ & (30) \\
5 & Total Perusahaan yang dijadikan Sampel & $\mathbf{1 9}$ \\
\hline Sumber: Data sekunder diolah, 2018
\end{tabular}

Sebanyak sembilan belas (19) perusahaan sektor properti, real estate, dan konstruksi di BEI berhasil memenuhi kriteria yang telah disebutkan dan dijadikan sampel penelitian, dengan rincian sebanyak enam (6) perusahaan tergolong sub sektor konstruksi dan bangunan dan tiga belas (13) perusahaan tergolong sub 
sektor properti dan real estate. Metode pengumpulan data dalam penelitian ini menggunakan metode observasi non partisipan. Jenis data yang digunakan dalam penelitian ini adalah data kuantitatif yaitu harga saham, dividen payout ratio, debt to equity ratio, serta total aset yang digunakan untuk mengukur ukuran perusahaan. Sumber data yang digunakan dalam penelitian ini adalah data sekunder berupa laporan keuangan tahunan yang diperoleh peneliti melalui situs resmi Bursa Efek Indonesia (www.idx.co.id) dan harga saham historis perusahaan diperoleh dari Yahoo Finance (www.finance.yahoo.com).

Penelitian ini menggunakan tiga tahap analisis yaitu statistik deskriptif, uji asumsi klasik, dan analisis regresi linear berganda. Statistik deskriptif memberikan gambaran atau deskripsi masing-masing variabel yang dilihat dari nilai nilai rata-rata, nilai maksimum, nilai minimum, varian dan standar deviasi (penyimpangan variabel terhadap nilai rata-rata). Pengujian asumsi klasik bertujuan untuk lebih meyakinkan atas kelayakan model yang dibuat, terutama untuk tujuan memprediksi apakah model yang digunakan memenuhi syarat penelitian. Analisis regresi linear berganda merupakan teknik analisis untuk mengetahui besarnya pengaruh variabel independen atau variabel bebas terhadap variabel dependen. Persamaan regresi dari penelitian ini adalah sebagai berikut:

$$
\begin{array}{ll}
\mathrm{Y} & =\alpha+\beta_{1} \mathrm{X}_{1}+\beta_{2} \mathrm{X}_{2}+\beta_{3} \mathrm{X}_{3}+\mathrm{e}_{\mathrm{i}} \\
\text { Keterangan : } & \\
\mathrm{Y} & =\text { Volatilitas harga saham } \\
\alpha & =\text { konstanta } \\
\beta & =\text { koefisien garis regresi } \\
\mathrm{e}_{\mathrm{i}} & =\text { standar error } \\
\mathrm{X}_{1} & =\text { kebijakan dividen } \\
\mathrm{X}_{2} & =\text { Leverage } \\
\mathrm{X}_{3} & =\text { Ukuran perusahaan }
\end{array}
$$

\section{HASIL DAN PEMBAHASAN}

Penelitian ini menggunakan sampel sebanyak 19 perusahaan dan periode selama 5 tahun yaitu tahun 2013-2017 sehingga jumlah data setiap variabel yang digunakan pada penelitian sebanyak 95 data.

Tabel 2.

Analisis Statistik Deskriptif

\begin{tabular}{lcrrrr}
\hline & N & \multicolumn{1}{c}{ Minimum } & Maximum & \multicolumn{1}{c}{ Mean } & Std. Deviation \\
\hline Volatilitas H S & 95 & 0,071 & 0,345 & 0,19288 & 0,060853 \\
DPR & 95 & 0,029 & 3,721 & 0,30316 & 0,394272 \\
DER & 95 & 0,282 & 5,278 & 1,47462 & 1,095633 \\
Ukuran Prs. & 95 & 27,918 & 32,215 & 29,92449 & 0,967549 \\
Valid N & 95 & & & & \\
Sumber: Data sekunder diolah, 2018 & & &
\end{tabular}

Berdasarkan hasil analisis statistik deskriptif, nilai terendah variabel volatilitas harga saham didapat dari perusahaan Metropolitan Kentjana Tbk (MKPI) pada tahun 2015 sebesar 0,071. Nilai tertinggi variabel volatilitas harga saham didapat dari perusahaan Perdana Gapuraprima Tbk (GPRA) pada tahun 
2017 sebesar 0,345. Nilai rata-rata volatilitas harga saham sebesar 0,19288, artinya sektor properti, real estate, dan konstruksi rata-rata mengalami pergerakan naik turunnya harga saham sebesar 19,28 persen dengan standar deviasi sebesar 0,060853 .

Nilai terendah variabel kebijakan dividen (DPR) didapat dari perusahaan Bekasi Fajar Industrial Estate (BEST) pada tahun 2014 sebesar 0,029. Nilai tertinggi variabel kebijakan dividen didapat dari perusahaan Plaza Indonesia Realty Tbk (PLIN) sebesar 3,721. Nilai rata-rata dividen payout ratio sebesar 0,30316 , artinya rata-rata perusahaan sektor properti, real estate, dan konstruksi memiliki tingkat pengembalian investasi sebesar 30,32 persen dengan standar deviasi sebesar 0,394272 .

Nilai terendah variabel leverage (DER) dimiliki oleh perusahaan Bekasi Fajar Industrial Estate (BEST) pada tahun 2014 sebesar 0,282. Nilai tertinggi DER dimiliki oleh perusahaan Adhi Karya (Persero) Tbk (ADHI) sebesar 5,278. Nilai rata-rata debt to equity ratio sebesar 1,47462 , artinya rata-rata perusahaanperusahaan sektor properti, real estate, dan konstruksi memiliki perbandingan antara total utang dengan modal sendiri sebesar 147,46 persen dengan standar deviasi sebesar 1,095633 .

Nilai terendah variabel ukuran perusahaan dimiliki oleh perusahaan Perdana Gapuraprima Tbk (GPRA) pada tahun 2013 sebesar 27,918. Nilai tertinggi variabel ukuran perusahaan dimiliki oleh perusahaan Waskita Karya (Persero) Tbk (WSKT) pada tahun 2017 sebesar 32,215. Nilai rata-rata logaritma natural total aset perusahaan sektor properti, real estate, dan konstruksi di BEI sebesar 29,92449 dengan standar deviasi sebesar 0,967549.

Uji asumsi klasik dilakukan sebelum dilakukan analisis regresi linear berganda. Uji asumsi klasik dilakukan untuk mengetahui kelayakan model yang dibuat sehingga model regresi yang dijadikan alat estimasi tidak bias. Uji asumsi klasik terdiri dari empat tahapan yaitu uji normalitas, uji autokorelasi, uji multikolinearitas, dan uji heteroskedastisitas.

Tabel 3.

Hasil Uji Normalitas

\begin{tabular}{|c|c|c|}
\hline & & Unstandardized Residual \\
\hline $\mathrm{N}$ & & 95 \\
\hline \multirow[t]{2}{*}{ Normal Parameters a,b } & Mean & 0,0000000 \\
\hline & Std. Deviation & 0,05563216 \\
\hline Most Extreme & Absolute & 0,080 \\
\hline \multirow[t]{2}{*}{ Differences } & Positive & 0,080 \\
\hline & Negative & $-0,054$ \\
\hline Kolmogorov-Smirnov Z & & 0,782 \\
\hline Asymp. Sig. (2-tailed) & & 0,573 \\
\hline
\end{tabular}

Uji normalitas dilakukan dengan uji statistik non-parametrik KolmogorovSmirnov (K-S). Berdasarkan hasil analisis, nilai signifikansi uji K-S sebesar 0,573 lebih besar dari $0,05($ sig. $=0,573>0,05)$ menunjukkan data variabel yang digunakan dalam penelitian berdistribusi normal. 
Tabel 4.

Hasil Uji Autokorelasi

\begin{tabular}{cccccc}
\hline Model & R & R Square & $\begin{array}{c}\text { Adjusted R } \\
\text { Square }\end{array}$ & $\begin{array}{c}\text { Std. Error of } \\
\text { the Estimate }\end{array}$ & $\begin{array}{c}\text { Durbin- } \\
\text { Watson }\end{array}$ \\
\hline 1 & $0,405^{\text {a }}$ & 0,164 & 0,137 & 0,56542 & 1,870 \\
\hline
\end{tabular}

Sumber: Data sekunder diolah, 2018

Uji autokorelasi dilakukan dengan melihat nilai Durbin-Watson. Penelitian ini menggunakan jumlah data (n) sebanyak 95 dan jumlah variabel bebas $\left(\mathrm{k}^{\prime}\right)$ sebanyak 3, maka diperoleh nilai nilai $\mathrm{dL}=1,602, \mathrm{dU}=1,732$, dan 4-dU $=2,268$ (4 - 1,732). Berdasarkan hasil analisis, nilai Durbin-Watson sebesar 1,870 berada diantara nilai dU dan 4-dU $(1,732<1,870<2,268)$ maka dapat dikatakan bahwa model regresi yang digunakan bebas dari autokorelasi.

Tabel 5.

Hasil Uji Multikolinearitas

\begin{tabular}{llcr}
\hline \multirow{2}{*}{ Model } & & \multicolumn{2}{c}{ Collinearity Statistics } \\
\cline { 3 - 4 } & & Tolerance & VIF \\
\hline 1 & (Constant) & 0,940 & 1,064 \\
& DPR & 0,924 & 1,082 \\
& DER & 0,882 & 1,133 \\
\hline & Ukuran Prs. & &
\end{tabular}

Uji multikolinearitas dilakukan dengan melihat nilai tolerance dan nilai variance inflation factor (VIF). Berdasarkan hasil analisis, dapat dilihat bahwa nilai tolerance ketiga variabel bebas yaitu kebijakan dividen (DPR), leverage (DER), dan ukuran perusahaan lebih besar daripada 0,10 (tolerance $=0,940$; $0,924 ; 0,882>0,10)$ dengan nilai VIF kurang dari 10 (VIF $=1,064 ; 1,082 ; 1,133$ $<10$ ) sehingga dapat disimpulkan bahwa tidak ada multikolinearitas antar variabel dalam model regresi.

Tabel 6.

Hasil Uji Heteroskedastisitas

\begin{tabular}{|c|c|c|c|c|c|c|}
\hline \multirow[b]{2}{*}{ Model } & & \multicolumn{2}{|c|}{$\begin{array}{c}\text { Unstandardized } \\
\text { Coefficients }\end{array}$} & \multirow{2}{*}{$\begin{array}{c}\begin{array}{c}\text { Standardized } \\
\text { Coefficients }\end{array} \\
\text { Beta }\end{array}$} & \multirow[b]{2}{*}{$\mathbf{T}$} & \multirow[b]{2}{*}{ Sig. } \\
\hline & & B & Std. Error & & & \\
\hline \multirow[t]{4}{*}{1} & (Constant) & 0,205 & 0,113 & & 1,811 & 0,074 \\
\hline & DPR & $-0,002$ & 0,009 & $-0,023$ & $-0,215$ & 0,830 \\
\hline & DER & 0,001 & 0,003 & 0,046 & 0,430 & 0,668 \\
\hline & Ukuran Prs. & $-0,005$ & 0,004 & $-0,157$ & $-1,425$ & 0,157 \\
\hline
\end{tabular}

Berdasarkan hasil analisis, nilai signifikansi dari ketiga variabel lebih besar daripada 0,05 dimana nilai signifikansi kebijakan dividen (DPR) sebesar 0,830, 
leverage (DER) sebesar 0,668, dan ukuran perusahaan sebesar 0,157 , sehingga dapat disimpulkan bahwa tidak terdapat heteroskedastisitas pada model regresi.

Analisis regresi linear berganda digunakan untuk mengetahui besarnya pengaruh variabel bebas yaitu kebijakan dividen, leverage, dan ukuran perusahaan terhadap variabel terikat yaitu volatilitas harga saham pada perusahaan sektor properti, real estate, dan konstruksi.

Tabel 7.

Ringkasan Hasil Analisis Regresi Linear Berganda

\begin{tabular}{|c|c|c|c|c|c|c|c|}
\hline \multirow[b]{2}{*}{ Mod } & & \multicolumn{2}{|c|}{$\begin{array}{c}\text { Unstandardized } \\
\text { Coefficients }\end{array}$} & \multirow[b]{2}{*}{$\mathbf{r}$} & \multirow[b]{2}{*}{$\mathbf{r}^{2}$} & \multirow[b]{2}{*}{$\mathbf{T}$} & \multirow[b]{2}{*}{ Sig. } \\
\hline & & B & $\begin{array}{c}\text { Std. } \\
\text { Error }\end{array}$ & & & & \\
\hline \multirow[t]{4}{*}{1} & (Constant) & 0,892 & 0,191 & & & 4,665 & 0,000 \\
\hline & DPR & $-0,031$ & 0,015 & 102 & 0,0104 & $-2,010$ & 0,047 \\
\hline & DER & 0,015 & 0,006 & 0,161 & 0,0259 & 2,673 & 0,009 \\
\hline & Ukuran Prs. & $-0,024$ & 0,006 & $-0,267$ & 0,0712 & $-3,706$ & 0,000 \\
\hline \multirow{2}{*}{\multicolumn{2}{|c|}{$\begin{array}{l}\text { Model } \\
1\end{array}$}} & $\mathrm{R}$ & $\mathrm{R}^{2}$ & F & Sig. & & \\
\hline & & 0,405 & 0,164 & 5,961 & 0,001 & & \\
\hline
\end{tabular}

Sumber: Data sekunder diolah, 2018

Berdasarkan hasil analisis, maka persamaan regresi linear berganda adalah sebagai berikut :

$$
\mathrm{Y}=0,892-0,031 \mathrm{X} 1+0,015 \mathrm{X} 2-0,024 \mathrm{X} 3+\mathrm{e}
$$

Persamaan regresi linear berganda tersebut menunjukkan arah masingmasing variabel bebas (kebijakan dividen, leverage, dan ukuran perusahaan) terhadap variabel terikat (volatilitas harga saham) dimana tanda positif menunjukkan pengaruh yang searah sedangkan pengaruh negatif menunjukkan pengaruh yang berlawanan.

Nilai koefisien regresi $\left(\beta_{1}\right)$ variabel kebijakan dividen yang diproksikan oleh dividend payout ratio (DPR) sebesar $-0,031$ berarti apabila DPR perusahaan meningkat sebesar 1 persen maka volatilitas harga saham perusahaan menurun sebesar 3,1 persen dengan asumsi ceteris paribus. Nilai koefisien regresi $\left(\beta_{2}\right)$ variabel leverage yang diproksikan oleh debt to equity ratio (DER) sebesar 0,015 berarti apabila DER perusahaan meningkat sebesar 1 persen maka volatilitas harga saham perusahaan meningkat sebesar 1,5 persen dengan asumsi ceteris paribus. Nilai koefisien regresi $\left(\beta_{3}\right)$ variabel ukuran perusahaan yang diproksikan oleh ln total aset sebesar $-0,024$ berarti apabila ukuran perusahaan ditingkatkan sebesar 1 satuan maka volatilitas harga saham perusahaan menurun sebesar 2,4 persen dengan asumsi ceteris paribus.

Uji kelayakan model dilakukan dengan melakukan uji koefisien determinasi $\mathrm{R}^{2}$ dan uji F. Uji koefisien determinasi mengukur seberapa jauh variabel terikat mampu dijelaskan oleh variabel bebas dalam model. Uji $\mathrm{F}$ digunakan untuk mengetahui apakah variabel independen yaitu kebijakan dividen, leverage, dan ukuran perusahaan memiliki pengaruh secara simultan terhadap variabel dependen yaitu volatilitas harga saham. 
Tabel 8.

Hasil Uji Koefisien Determinasi $\left(\mathbf{R}^{2}\right)$

\begin{tabular}{ccccc}
\hline Model & $\mathbf{R}$ & R Square & $\begin{array}{c}\text { Adjusted } \mathbf{R} \\
\text { Square }\end{array}$ & $\begin{array}{c}\text { Std. Error of the } \\
\text { Estimate }\end{array}$ \\
\hline 1 & $0,405^{\mathrm{a}}$ & 0,164 & 0,137 & 0,56542
\end{tabular}

Sumber: Data sekunder diolah, 2018

Berdasarkan hasil analisis, nilai $\mathrm{R}^{2}$ dalam penelitian ini adalah 0,164 , sebesar 16,4 persen variasi dari variabel volatilitas harga saham dipengaruhi oleh variasi variabel kebijakan dividen, leverage, dan ukuran perusahaan, sedangkan sisa 83,6 persen dipengaruhi oleh faktor lain yang tidak dimasukkan dalam model regresi penelitian ini.

Tabel 9.

Hasil Uji F

\begin{tabular}{llcrrrr}
\hline Model & & $\begin{array}{c}\text { Sum of } \\
\text { Squares }\end{array}$ & df & $\begin{array}{c}\text { Mean } \\
\text { Square }\end{array}$ & F & Sig. \\
\hline 1 & Regression & 0,057 & 3 & 0,019 & 5,961 & 0,001 \\
& Residual & 0,291 & 91 & 0,004 & & \\
& Total & 0,348 & 94 & & & \\
\hline
\end{tabular}

Berdasarkan hasil analisis, model regresi memiliki nilai $F_{\text {hitung }}$ sebesar 5,961 dengan nilai signifikansi kurang dari 0,05 yaitu sebesar 0,001 . Uji $F$ dilakukan dengan melihat derajat bebas $\left(\mathrm{v}_{1}=\mathrm{k}-1\right) ;\left(\mathrm{v}_{2}=\mathrm{n}-\mathrm{k}\right)$. Nilai $\mathrm{F}_{\text {tabel }}$ yang diperoleh dari derajat bebas 3;91 (v1 $=4-1$; v2 $=95-4)$ adalah 2,70. Dengan diperolehnya nilai $F_{\text {hitung }}$ lebih besar daripada nilai $F_{\text {tabel }}(5,961>2,70)$ dan nilai signifikansi lebih kecil daripada taraf nyata $(0,001<0,05)$ maka dapat disimpulkan bahwa variabel kebijakan dividen (DPR), leverage (DER), dan ukuran perusahaan berpengaruh signifikan secara simultan terhadap volatilitas harga saham.

Uji $\mathrm{t}$ digunakan untuk mengetahui bagaimana pengaruh masing-masing variabel bebas yaitu kebijakan dividen (DPR), leverage (DER), dan ukuran perusahaan secara parsial terhadap variabel terikat yaitu volatilitas harga saham.

Tabel 10.

Hasil Uji t

\begin{tabular}{rlrrrr}
\hline & & & & & \\
\multicolumn{1}{c}{ Model } & & B & $\mathbf{r}^{2}$ & \multicolumn{1}{c}{ T } & Sig. \\
\hline 1 & (Constant) & 0,892 & & 4,665 & 0,000 \\
& DPR & $-0,031$ & 0,0104 & $-2,010$ & 0,047 \\
& DER & 0,015 & 0,0259 & 2,673 & 0,009 \\
& Ukuran Prs. & $-0,024$ & 0,0712 & $-3,706$ & 0,000 \\
\hline
\end{tabular}

Sumber: Data sekunder diolah, 2018

Berdasarkan hasil analisis, variabel kebijakan dividen (DPR) memiliki $\mathrm{r}^{2}$ sebesar 0,0104 . Nilai $\mathrm{r}^{2}$ memiliki arti bahwa sebesar 1,04 persen variasi volatilitas harga saham dipengaruhi oleh variasi kebijakan dividen yang diproksikan dengan DPR. Uji t dilakukan dengan melihat derajat bebas (n-k) dan taraf nyata, dimana 
derajat bebas $=91(95-4)$ dan taraf nyata 0,05 sehingga di dapat nilai $t_{\text {tabel }}=$ 1,6617. Uji t yang dilakukan adalah uji sisi negatif. Oleh karena nilai thitung lebih kecil daripada - $t_{\text {tabel }}(-2,010<-1,6617)$ dengan nilai signifikansi lebih kecil daripada 0,05 (sig. $=0,047<0,05)$ menunjukkan bahwa kebijakan dividen berpengaruh negatif signifikan terhadap volatilitas harga saham.

Variabel leverage (DER) memiliki nilai $\mathrm{r}^{2}$ sebesar 0,0259 . Nilai $\mathrm{r}^{2}$ memiliki arti bahwa sebesar 2,59 persen variasi volatilitas harga saham dipengaruhi oleh variasi leverage yang diproksikan dengan DER. Uji t yang dilakukan adalah uji sisi positif. Nilai thitung lebih besar daripada tabel $(2,673>1,6617)$ dengan nilai signifikansi lebih kecil daripada 0,05 yaitu sebesar 0,009 $($ sig. $=0,009<0,05)$ menunjukkan bahwa leverage berpengaruh positif signifikan terhadap volatilitas harga saham.

Variabel ukuran perusahaan memiliki nilai $r^{2}$ sebesar 0,0712. Nilai $r^{2}$ memiliki arti bahwa 7,12 persen variasi volatilitas harga saham dipengaruhi oleh variasi ukuran perusahaan yang diproksikan dengan ln total aset. Uji t yang dilakukan adalah uji sisi negatif. Nilai $t_{\text {hitung }}$ lebih kecil daripada $-t_{\text {tabel }}(-3,706<$ $-1,6617)$ dengan nilai signifikansi lebih kecil daripada 0,05 yaitu sebesar 0,000 (sig. $=0,000<0,05)$ menunjukkan bahwa ukuran perusahaan berpengaruh negatif signifikan terhadap volatilitas harga saham.

Berdasarkan hasil analisis regresi linear berganda pada penelitian ini menunjukkan nilai signifikansi uji t kebijakan dividen sebesar 0,47, lebih kecil daripada taraf nyata yaitu 0,05 dengan nilai $\beta$ sebesar $-0,031$. Hasil tersebut menunjukkan bahwa kebijakan dividen yang dalam penelitian ini diproksikan dengan dividend payout ratio memiliki pengaruh negatif signifikan terhadap volatilitas harga saham. Dengan demikian hipotesis pertama $\left(\mathrm{H}_{1}\right)$ yang menyatakan kebijakan dividen berpengaruh negatif terhadap volatilitas harga saham diterima. Hasil ini sesuai dengan signaling theory yang menyatakan suatu kenaikan dividen biasanya memberikan sinyal kepada para investor bahwa manajemen perusahaan meramalkan suatu penghasilan yang baik di masa mendatang. Perusahaan yang memiliki rasio pembayaran dividen yang tinggi akan menarik minat investor dan mengurangi ketidakpastian investor dalam menanamkan dananya ke dalam perusahaan. Dengan tingkat kepastian yang lebih besar, perusahaan yang membagikan dividen akan memiliki harga saham yang tinggi dan cenderung tidak berubah, dengan kata lain memiliki volatilitas yang lebih rendah. Hasil penelitian ini sesuai dengan hasil penelitian yang dilakukan oleh Nazir et al. (2012) di Pakistan, Profilet dan Bacon (2013) di Amerika Serikat, Al-Shawawreh (2014) di Yordania, serta Hooi et al. (2015) di Malaysia.

Hasil analisis menunjukkan bahwa leverage memiliki nilai signifikansi sebesar 0,009 , lebih kecil daripada taraf nyata 0,05 dengan nilai $\beta$ sebesar 0,015 . Hasil tersebut menunjukkan bahwa leverage memiliki pengaruh positif signifikan terhadap volatilitas harga saham. Dengan demikian, hipotesis kedua $\left(\mathrm{H}_{2}\right)$ yang menyatakan leverage berpengaruh positif terhadap volatilitas harga saham diterima. Semakin tinggi rasio total utang dengan modal sendiri perusahaan, akan meningkatkan risiko perusahaan karena kecenderungan perusahaan bergantung pada utang akan mengakibatkan pengurangan laba untuk memenuhi kewajiban membayar bunga utang. Hasil ini sesuai dengan trade off theory yang menyatakan 
perusahaan yang banyak melakukan pendanaan dengan utang memiliki risiko yang tinggi untuk mengalami kesulitan keuangan akibat pembayaran bunga tetap yang terlalu besar. Risiko yang meningkat akan menurunkan minat investor untuk membeli saham perusahaan sehingga volatilitas harga saham akan meningkat. Hasil penelitian ini sesuai dengan hasil penelitian terdahulu yang dilakukan oleh Nazir et al. (2014) di Pakistan dan Jannah dan Haridhi (2016) di Indonesia.

Hasil analisis menunjukkan bahwa ukuran perusahaan yang diproksikan dengan In total aset memiliki nilai sigifikansi 0,000 , lebih kecil daripada taraf nyata yaitu 0,05 dengan nilai $\beta$ sebesar $-0,024$. Hasil tersebut menunjukkan bahwa ukuran perusahaan memiliki pengaruh negatif signifikan terhadap volatilitas harga saham. Dengan demikian, hipotesis ketiga $\left(\mathrm{H}_{3}\right)$ yang menyatakan ukuran perusahaan berpengaruh negatif terhadap volatilitas harga saham diterima. Penelitian ini membuktikan sinyal yang diberikan manajemen perusahaan dapat memberikan petunjuk bagi investor tentang bagaimana memandang prospek perusahaan. Perusahaan dengan total aset yang besar menunjukkan bahwa arus kas perusahaan dianggap memiliki prospek yang baik, serta mencerminkan perusahaan relatif lebih stabil dan lebih mampu menghasilkan laba dibandingkan perusahaan dengan aset kecil. Semakin besar perusahaan, umumnya memiliki informasi yang lebih mudah diakses sehingga dapat mengurangi ketidakpastian investor dalam menanamkan modalnya dan menurunkan volatilitas harga saham. Hasil penelitian ini sesuai dengan hasil penelitian terdahulu yang dilakukan oleh Profilet dan Bacon (2013) di Amerika Serikat, Anastasia dan Firnanti (2014) di Indonesia, Qudah dan Yusuf (2015) di Yordania, serta Selpiana dan Badjra (2018) di Indonesia.

\section{SIMPULAN}

Simpulan yang diperoleh berdasarkan pembahasan hasil penelitian adalah kebijakan dividen berpengaruh negatif terhadap volatilitas harga saham, leverage berpengaruh positif terhadap volatilitas harga saham, dan ukuran perusahaan berpengaruh negatif terhadap volatilitas harga saham. Berdasarkan simpulan tersebut, peneliti memberikan saran-saran sebagai berikut: bagi perusahaan sektor properti, real estate, dan konstruksi disarankan untuk mempertimbangkan kebijakan dividen, leverage, dan ukuran perusahaan sebagai dasar pengambilan keputusan keuangan karena dapat mempengaruhi pergerakan harga saham, bagi investor diharapkan untuk lebih memperhatikan faktor-faktor yang mempengaruhi volatilitas harga saham agar dapat mengambil keputusan berinvestasi yang tepat dan meminimalisir risiko kerugian, dan bagi peneliti selanjutnya disarankan untuk meneliti variabel lain seperti volume perdagangan saham, inflasi, dan faktor eksternal maupun faktor internal lain yang berpengaruh terhadap volatilitas harga saham. Penelitian selanjutnya juga dapat dilakukan pada sektor yang berbeda.

\section{REFERENSI}

Al-Shawawreh, F. K. (2014). The Impact of Dividend Policy on Share Price Volatility: Empirical Evidence from Jordanian Stock Market. European Journal of Business and Management, 6(38), 133-142. https://www.iiste.org/Journals/index.php/EJBM/article/view/18784 
Ananda, A. \& Mahdy. (2015). Faktor-Faktor yang Mempengaruhi Volatilitas Harga Saham pada Perusahaan-Perusahaan Konsumsi yang Terdaftar di Bursa Efek Indonesia. Jurnal Akuntansi dan Bisnis, 1(1), 97-110. https://doi.org/10.24843/EJA.2018.v24.i03.p19

Anastasia \& Finanti, F. (2014). Faktor-Faktor yang Mempengaruhi Volatilitas Harga Saham pada Perusahaan Publik Nonkeuangan. Jurnal Bisnis dan Akuntansi, 6(2), 95-102. http://jurnaltsm.id/index.php/JBA/ article/view/80

Ardiansyah, I. \& Isbanah, Y. (2017). Analisis Pengaruh Dividen, Pertumbuhan Aset, Ukuran Perusahaan, dan Leverage Terhadap Volatilitas Harga Saham. Jurnal Akuntansi dan Keuangan, 5(3), 55-61. http://dx.doi.org/10.17509/jrak.v5i3.9227

Brigham, E. F. \& Houston, J. F. (2011). Dasar-Dasar Manajemen Keuangan (Edisi Sebelas, Buku 2). Jakarta: Salemba Empat.

Dewi, N. M. A. K. \& Suaryana, I. G. N .A. (2016). Pengaruh Volume Perdagangan Saham, Leverage, dan Tingkat Suku Bunga Terhadap Volatilitas Harga Saham. E-Jurnal Akuntansi Unud, 17(2), 1112-1140. https://ojs.unud.ac.id/index.php/Akuntansi/article/view/20226

Fahmi, I. (2012). Manajemen Investasi: Teori dan Soal Jawab. Jakarta: Salemba Empat.

Fahmi, I. (2016). Pengantar Manajemen Keuangan: Teori dan Soal Jawab. Bandung: Alfabeta

Gunarathne, U. G. V. D. D., Priyadarshanie, W. A. N., \& Samarkoon, S. M. R. K. (2015). Impact of Dividend Policy on Stock Price Volatility and Market Value of The Firm: Evidence from Sri Lankan Manufacturing Companies. Corporate Ownership \& Control, 13(3), 219-225.

https://doi.org/10.2139/ssrn.2699697

Harahap, S. S. (2009). Analisis Kritis atas Laporan Keuangan (Edisi Satu). Jakarta: PT. Raja Grafindo Persada.

Hartono, J. (2015). Teori Portofolio dan Analisis Investasi (Edisi Sepuluh). Yogyakarta: BPFE

Hashemijoo, M., Ardekani, A. M., \& Younesi, M. (2012). The Impact of Dividend Policy on Share Price Volatility in The Malaysian Stock Market. Journal of Business Studies Quarterly, 4(1), 111-129. https://ssrn.com/abstract $=2147458$ 
Hooi, S. E., Albaity, M., \& Ibrahimy, A. I. (2015). Dividend Policy and Share Price Volatility. Investment Management and Financial Innovations, 12(1), 226-234. https://dx.doi.org/10.1097/GME.0000000000000563

Husnan, S. \& Pudjiastuti, E. (2012). Dasar-Dasar Manajemen Keuangan (Edisi Enam). Yogyakarta: UPP STIM YKPN

Hussainey, K., Mgbame, C. O., \& Chijoke-Mgbame, A. M. (2011). Dividend Policy and Share Price Volatility: UK Evidence. Journal of Risk Finance, 12(1), 57-68. https://doi.org/10.1108/15265941111100076

Jannah, R. \& Haridhi, M. (2016). Pengaruh Kebijakan Dividen, Earning Volatility, dan Leverage terhadap Volatilitas Harga Saham pada Perusahaan Non-Financing yang Terdaftar di Bursa Efek Indonesia Tahun 2010-2014. Jurnal Ilmiah Mahasiswa Ekonomi Akuntansi, 1(1), 133-148. www.jim.unsyiah.ac.id/EKA/article/view/761

Khan, M. Y., Waleed, M. H. A. B., Wajid, K., \& Anam, J. (2017). Dividend Policy and Share Price Volatility "Evidence from Karachi Stock Exchange". ELK Asia Pacific Journal of Finance and Risk Management, 8(1), 59-73. https://dx.doi.org/10.16962/EAPJSS/issn.2394-9392/2015

Kontan.co.id News Data Financial Tools. 2018. https://investasi.kontan.co.id/news/merangkak-naik-apakah-ini-pertandasaham-properti-mulai-bangkit Diakses pada 30 April 2018

Lashgari, Z. \& Ahmadi, M. (2014). The Impact of Dividend Policy on Stock Price Volatility In The Tehran Stock Exchange. Kuwait Chapter of Arabian Journal of Business and Management Review, 3(10), 273-281. https://dx.doi.org/10.12816/0018408

Kasmir. (2014). Analisis Laporan Keuangan. Jakarta: PT Raja Grafindo Persada Khurniaji, A. W. \& Raharja, S. (2013). Hubungan Kebijakan Dividen (Dividend Payout Ratio dan Dividend Yield) terhadap Volatilitas Harga Saham di Perusahaan-perusahaaan yang Terdaftar di Bursa Efek Indonesia. Diponegoro Journal of Accounting, 2(3), 1-10. https://ejournal3.undip.ac.id/index.php/accounting/article/view/3384/3317

Madura, J. (2014). Financial Markets and Institutions (1 $11^{\text {th }}$ Edition). Boston: Cengage Learning

Mardiyati, U., Ahmad, G. N., \& Putri, R. (2012). Pengaruh Kebijakan Dividen, Kebijakan Hutang, dan Profitabilitas terhadap Nilai Perusahaan Manufaktur yang Terdaftar di Bursa Efek Indonesia (BEI) Periode 2005-2010. Jurnal Riset Manajemen Sains Indonesia, 3(1), 1-17.

http://journal.unj.ac.id/unj/index.php/jrmsi/article/view/770 
Murniati, S. (2015). Faktor-Faktor yang Berpengaruh Terhadap Harga Saham Perusahaan Makanan dan Minuman yang Terdaftar di Bursa Efek Indonesia. Jurnal Aplikasi Manajemen, 9(3), 137-144.

Nazir, N., Ali, A., \& Sabir, H. (2014). Impact of Dividend Policy on Stock Price Volatility:A Case Study of Pakistani Capital Market. European Journal of Business and Management. 6(11), 49-61. https://www.iiste.org/Journals/index.php/EJBM/article/view/12215

Nazir, M. S., Abdullah, \& Nawas, M. M. (2012). How Dividend Policy Affects Volatility of Stock Prices of Financial Sector Firms of Pakistan. American Journal of Scientific Research, 61, 132-139.

http://www.ciitlahore.edu.pk/Papers/Abstracts/146-8588087138215633308.pdf

Nazir, M. S., Nawaz, M. M., Anwar, W., \& Ahmed, F. (2010). Determinants of Stock Price Volatility in Karachi Stock Exchange: The Mediating Role of Corporate Dividend Policy. International Research Journal of Finance and Economics, (55), 100-107.

http://ciitlahore.edu.pk/Papers/Abstracts/146-8589069429892551798.pdf

Priana, I. W. K. \& Muliartha, K. RM. (2017). Pengaruh Volume Perdagangan Saham, Leverager, dan Dividend Payout Ratio pada Volatilitas Harga Saham. E-Jurnal Akuntansi Universitas Udayana, 20(1), 1-29. https://doi.org/10.24843/EJA.2017.v20.i01.p01

Profilet, K. A. \& Bacon, F. W. (2013). Dividend Policy and Stock Price Volatility In the U.S. Equity Capital Market. Journal of Business and Behaviour Sciences, 25(2), 63-72. https://digitalcommons.longwood.edu/etd/145/

Qudah, A. A. \& Yusuf, A. (2015). Stock Price Volatility and Dividend Policy in Jordanian Firms. Research Journal of Finance and Accounting, 6(22), 149159. https://ssrn.com/abstract $=2871888$

Ramadan, I. Z. (2013). Dividend Policy and Price Volatility: Empirical Evidence from Jordan. International Journal of Academic in Accounting, Finance, and Management Sciences, 3(2), 15-22. http://hrmars.com/admin/pics/1864.pdf

Rohmawati, I. (2017). Pengaruh Volume Perdagangan, Dividend Payout Ratio, dan Inflasi terhadap Volatilitas Harga Saham pada Perusahaan yang Terdaftar dalam Indeks LQ45 Tahun 2011-2015. Jurnal Pendidikan dan Ekonomi, 6(1), 38-45. http://journal.student.uny.ac.id/ojs/index.php/ ekonomi/article/download/6071/5798

Sartono, A. (2014). Manajemen Keuangan: Teori dan Aplikasi (Edisi Empat). Yogyakarta: BPFE 
Selpiana, R. \& Badjra, I. B. (2018). Pengaruh Kebijakan Dividen, Nilai Tukar, Leverage, dan Firm Size, Terhadap Volatilitas Harga Saham. E-Jurnal Manajemen Unud, 7(3), 1682-1712.

https://doi.org/10.24843/EJMUNUD.2018.v7.i03.p20

Sharif, I., Ali, A., \& Jan, F. A. (2017). Effect of Dividend Policy on Stock Prices. Journal of Management Info, 4(1), 19-28.

http://dx.doi.org//10.31580/jmi.v6i1.47

Sulia \& Rice. (2013). Analisa Faktor-Faktor yang Mempengaruhi Harga Saham Perusahaan LQ45 di Bursa Efek Indonesia. Jurnal Wira Ekonomi Mikroskil, 3(1), 21-30.

https://www.mikroskil.ac.id/ejurnal/index.php/jwem/article/view/198

Tandelilin, E. (2010). Portofolio dan Investasi Teori dan Aplikasi (Edisi Satu). Yogyakarta: Kanisius

Theresia, P. \& Arilyn, E. J. (2015). Pengaruh Dividen, Ukuran Perusahaan, Hutang Jangka Panjang, Earning Volatility, Pertumbuhan Aset, Trading Volume, dan Kepemilikan Manajerial Terhadap Volatilitas Harga Saham. Jurnal Bisnis dan Akuntansi, 17(2), 197-204.

http://jurnaltsm.id/index.php/JBA/article/view/31

Wiagustini, N. L. P. (2014). Manajemen Keuangan. Denpasar: Udayana University Press

Zakaria, Z., Muhammad, J., \& Zulkifli, A. H. (2012). The Impact of Dividend Policy on The Share Price Volatility: Malaysian Construction and Material Companies. International Journal of Economics and Management Sciences. 2(5), 01-08. https://www.iiste.org/Journals/index.php/EJBM/article/view File/12215/12568 